\title{
The use of "High Dose" Dexmedetomidine in a Patient with Critical Tracheal Stenosis and Anterior Mediastinal Mass
}

\author{
C. Voscopoulos ${ }^{1,2}$, F.L. Kirk ${ }^{1}$, M. Lovrincevic ${ }^{1}$ and M. Lema ${ }^{1, *}$ \\ ${ }^{I}$ University at Buffalo, Department of Anesthesiology, Perioperative and Pain Medicine, Buffalo, NY, USA \\ ${ }^{2}$ Brigham and Women's Hospital, Harvard Medical School, Department of Anesthesiology, Perioperative and Pain \\ Medicine, Boston, MA, USA
}

\begin{abstract}
The anterior medial mass patient continues to offer great challenges for the anesthesiologist. As such, newer and safer methods of providing anesthetic care are continually being sought. To this end, there is a growing body of evidence that may suggest that higher than Food and Drug Administration approved dosages of dexmedetomidine may offer another option in the arsenal of the anesthesiologist in this patient population.

We recently cared for a middle aged male who presented with a large mediastinal mass, extrinsic compression critical tracheal stenosis, superior vena cava syndrome, and massive supraclavicular lymphadenopathy, scheduled for tracheal stent placement, biopsy, and diagnostic evaluation of the esophagus. After reviewing anesthetic options, we deemed the safest technique available to us to be the use of a high dose dexmedetomidine based technique with continuous infusion rate of $2 \mathrm{mcg} / \mathrm{kg} / \mathrm{hr}$. Spontaneous respirations were maintained throughout the case, with a stable heart rate and blood pressure, and our patient tolerated the procedure without complications.
\end{abstract}

Keywords: Alpha-2 agonist, clonidine, alpha-2 receptor, dexmedetomidine, mediastinal mass.

\section{INTRODUCTION}

General anesthesia in patients with an anterior mediastinal mass has been associated with hemodynamic and airway collapse. The anterior mediastinal space is largely composed of the thymus, the middle mediastinum contains the pericardium, heart, ascending aorta, aortic arch, and the great vessels, while the posterior mediastinum contains the tracheobronchial tree, esophagus, descending aorta, and neural structures. As such, compressive physiology may originate from masses of the thymus, thyroid, lung, airway, pleura, pericardium, lymphatic, or possibly other tissues. Morbidity is secondary to compression of the vital structures within the middle and posterior mediastinum.

In limited case series, the incidence of serious complications with general anesthesia in this patient population is up to $20 \%$ [1]. Positional dyspnea or orthopnea and stridor are ominous signs that may predict the probability of complications [2-5]. Patients develop symptoms, and have elevated risk of perioperative complications, when the reduction in tracheal cross-sectional area exceeds $50 \%$, while a reduction in tracheal cross-sectional area less than $50 \%$ indicates of a lower risk of perioperative complications [1, 3, 6-9]. However, if the patient has coexisting compression of a mainstem bronchi, the perioperative risk for complete airway collapse may be significantly higher [4]. The combination of left mainstem bronchial compression and right pulmonary

*Address correspondence to this author at the University at Buffalo, Department of Anesthesiology, Critical Care, and Pain Medicine, Buffalo, NY, USA; Tel: 716-829-6102; Fax: 716-829-3640; E-mail: mlema@buffalo.edu artery compression has been reported to cause catastrophic complete ventilation-perfusion mismatch $[1,10,11]$. Additionally, separate from airway compression, the presence of a pericardial effusion may be associated with intraoperative cardiovascular complications [3].

Unfortunately, there is a paucity of evidence providing guidance on quantifying risk and planning the safe conduct of anesthesia in patients with a symptomatic mediastinal mass [1]. It is currently believed that high risk patients are best managed with an anesthetic plan that emphasizes the maintenance of spontaneous ventilation, with the availability of cardiopulmonary bypass as the option of last resort [1]. This is largely because during general anesthesia with volatile agents, the functional residual capacity (FRC) is reduced by approximately $20 \%$ [12]. The most likely mechanism is the loss of inspiratory muscle tone of the muscles acting on the rib cage, elastic recoil of the chest wall, cephalad displacement of the diaphragm, with gas trapping acting as an additional mechanism [12]. The effect is compression atelectasis and increases in intrapulmonary shut and areas of low ventilation to perfusion. Neuromuscular blocking agents, if used in a multimodal plan for general anesthesia, can further compromise this physiology, as can many intravenous anesthetic agents with the possible exception of ketamine used in low doses. Furthermore, the abolishment of spontaneous (negative pressure) breathing decreases the transpleural pressure gradient which can lead to airway collapse. Additionally, the use of mechanical ventilation (positive pressure) may further increase intrathoracic pressures worsening the already high intrathoracic pressures related to the thoracic mass physiology [13]. 
When biopsy is desired for the planning of medical management, avoidance of general anesthesia by the use of local anesthesia alone or in combination with sedation has been described in case series of both adults and children [3-5]. Should a patient present with an already life threatening airway compromise, airway stenting can be undertaken as a temporizing measure. This procedure requires significantly more anesthetic depth to allow the patient to tolerate this course of action while attempting to maintain spontaneous ventilation.

In 1988, a new alpha-2 adrenoreceptor $\left(\alpha_{2}\right)$ agonist anesthetic, dexmedetomidine, was introduced [14]. Currently, the chief clinical application of dexmedetomidine is for sedation and anaesthesia $[15,16]$. Upon presentation of a middle aged male with a large mediastinal mass, extrinsic compression critical tracheal stenosis, superior vena cava syndrome, and massive supraclavicular lymphadenopathy, scheduled for tracheal stent placement and diagnostic evaluation of the esophagus, we determined that the use of a higher than current Food and Drug Adminisration (FDA) approved dose dexmedetomidine based technique was the best option for our patient. Currently, this technique has been described best in the pediatric population, with only a few published adult reports.

\section{CASE}

A 55 year old male, $65 \mathrm{~kg}$, American Society of Anesthesiologist's Class IV patient, with a past medical history significant for gastroesophageal reflux disease, a recent deep venous thrombosis, 30 pack year tobacco use, alcoholism, on no medications upon admission, presented with progressive dysphagia over a 1-2 month period, with interval weight loss of 50 pounds during the past year. Initial dysphagia was to solid foods, which progressed to soft foods, followed by fluids, with eventual difficulty in handling saliva. Over the past
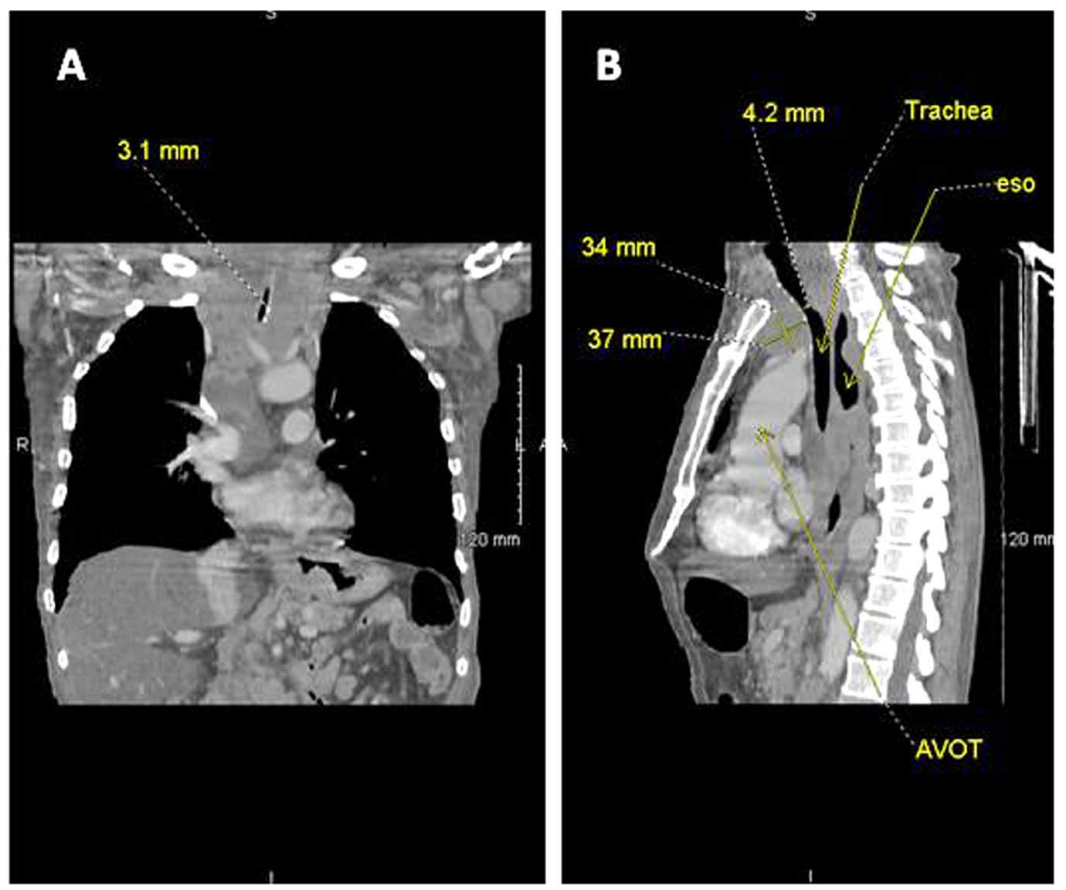

Fig. (1). External Compression Tracheal Stenosis. This contrast enhanced computed tomographic image shows external tracheal compression. In image $\mathbf{A}$, the narrowest portion of tracheal compression was measured at $3.1 \mathrm{~mm}$. Image $\mathbf{B}$ shows an anterior mediastinal mass measuring $34 \mathrm{~mm}$ by $37 \mathrm{~mm}$, with a tracheal narrowing of $4.2 \mathrm{~mm}$. Esophagus (eso), Aortic Valve Outflow Track (AVOT).

2-4 weeks, the patient also developed massive neck swelling and bilateral upper extremity edema, with dyspnea on exertion and vocal hoarseness.

A contrast enhanced computerized tomographic imaging (CT) scan of the chest revealed extensive abnormal soft tissue attenuation in the mediastinum extending to the neck base and supraclavicular regions, bilateral thrombi in the upper extremity veins, and tracheal lumen narrowing, with the narrowest portion being only $3.1 \mathrm{~mm}$ in diameter (Fig. 1). This represented a greater than $87 \%$ narrowing (patient's normal tracheal diameter was $24.5 \mathrm{~mm}$, within the normal range for males of $22.3-25.5 \mathrm{~mm}$ ) [17]. In addition, circumferential mid to distal esophageal wall thickening was noted extending downward to the proximal stomach.

Due the patient's risk of pending catastrophic airway collapse, he was scheduled for tracheal stent placement, diagnostic evaluation of the esophagus (EGD), and needle biopsy. We were consulted to provide his anesthetic care.

Airway exam revealed Malampati Class III, limited neck extension and flexion, neck circumference over $51 \mathrm{~cm}$, hypomandibular space firmness, inability to handle salivary gland secretions, and diffuse erythematic swelling of all visualized oral pharyngeal structures. Upon reclining toward the supine position, at approximately 75 degrees he became immediately orthopneic and experienced a severe choking sensation. There was no position, supine, prone, or lateral, in which the patient could tolerate if he declined below the 75 degree erect position. After additional surgical consultation regarding airway management, a primary airway via cricothyriodotomy or tracheostomy was not deemed feasible.

Our general anesthetic plan was to maintain our patient's supine position as tolerated (75-90 degree position), and maintain spontaneous ventilation throughout the case. To 
accomplish this goal, we choose to use a "high dose" dexmedetomidine based anesthetic.

Dexmedetomidine was delivered, based on actual patient body weight, at $1 \mathrm{mcg} / \mathrm{kg} / \mathrm{hr}$ for $10 \mathrm{~min}$, and raised to $2 \mathrm{mcg} / \mathrm{kg} / \mathrm{hr}$ for the remainder of the 60 minute case. This regimen was supplemented by $15 \mathrm{mcg} / \mathrm{kg} / \mathrm{min}$ of propofol, used primarily as a means to provide for quicker deepening of anesthetic depth if needed, and $4 \mathrm{mg}$ of midazolam.

Throughout the procedure, our patient maintained spontaneous respirations, and was non-responsive to surgical manipulation. We also encountered stable hemodynamics in which heart rate and blood pressure were maintained within twenty percent of baseline (systolic blood pressure 112-130, diastolic blood pressure 68-80, heart rate 112-120). The initial deployment of the tracheal stent proceeded uneventful, however, original placement, as confirmed by fluoroscopy, revealed the stent was placed to distally. The stent was then manually retracted into proper positioning, again with our patient being non-responsive to this stimulation. EGD and biopsy then followed, again with the patient being able to fully tolerate these procedures without the need for increased anesthetic requirements.

\section{DISCUSSION}

In 1999, the US FDA approved the use of dexmedetomidine for two indications and usages; sedation of initially intubated and mechanically ventilated patients during treatment in an intensive care setting, continuous infusion not to exceed 24 hours, and, sedation of non-intubated patients prior to and/or during surgical and other procedures. Approved dosages are as follows.1) For intensive care unit sedation: generally initiate at $1 \mathrm{mcg} / \mathrm{kg}$ over 10 minutes, followed by a maintenance infusion of 0.2 to $0.7 \mathrm{mcg} / \mathrm{kg} / \mathrm{hr}$. 2) For procedural sedation: generally initiate at $1 \mathrm{mcg} / \mathrm{kg}$ over 10 minutes, followed by a maintenance infusion initiated at $0.6 \mathrm{mcg} / \mathrm{kg} / \mathrm{hr}$ and titrated to achieve desired clinical effect with doses ranging from 0.2 to $1 \mathrm{mcg} / \mathrm{kg} / \mathrm{hr} .3$ ) Dosage reduction may need to be considered in the elderly.

Since dexmedetomidine can maintain a patient's spontaneous ventilation with normal $\mathrm{Pa}_{\mathrm{CO} 2}$, it is an ideal agent for use in attempts to secure a critically compromised airway. Even at very high doses of dexmedetomidine, the respiratory system can remain relatively unchanged. (See Table 1) Its additional antisialagogue properties are beneficial as well. As such, its value has been recognized in use as the sole sedative in awake intubation in the management of the difficult and critical airway in FDA approved dosages [18]. However, in true airway catastrophes, as presented in the case here, the level of analgesia and sedation achieved with the FDA recommended dosage may not be sufficient for the prescribed procedure. To this end, only a small handful of reports exist in the literature on the use of higher than FDA approved doses of dexmedetomidine in adults [19-25].

Higher doses of dexmedetomidine appear to be better studied in the pediatric literature, where a large scale retrospective study of 747 pediatric patients scheduled for magnetic resonance imaging (MRI), in which doses of $2 \mathrm{mcg} / \mathrm{kg} / \mathrm{hr}$ are used as the sole sedative in their protocol, had a 97.6\% success rate [26]. Also within the pediatric literature, as judged by MRI, it has been noted that with the use of dexmedetomidine in doses of $1 \mathrm{mcg} / \mathrm{kg} / \mathrm{hr}$ or $3 \mathrm{mcg} / \mathrm{kg} / \mathrm{hr}$, upper airway changes in children with no OSA are small in magnitude and do not appear to be associated with clinical signs of airway obstruction [27]. This said, caution is advised, as has been shown in goats with the use of clonidine, $\alpha_{2}$ stimulation preferentially decreased the activity of the posterior cricoarytenoid, cricothyriod, and inferior pharyngeal constrictor muscles while increasing thyroaryteniod and middle pharyngeal constrictor electromyogram activities [28]. As such, clonidine-induced apneas were shown to be associated with continuous tonic activation of laryngeal thyroaryteniod and middle pharyngeal constrictor adductors, leading to airway closure and arterial oxygen desaturation; these effects being reversed by selective $\alpha_{2}$ blockade with SKF-86466 [28]. It is postulated that these effects are due to hyperpolarization or attenuation of the activity of central respiratory-related neurons that have been shown to slow or inhibit breathing in animals and humans [15, 29-39]. This said, it is important to note that the effects of $\alpha_{2}$ agonists appear to be species specific [40,41]. As such, though $\alpha_{2}$ agonists are ubiquitously distributed throughout the CNS in humans, including in brainstem regions which are instrumental in control of breathing, such as the nucleus tractus solitaries, nucleus ambiguous, and ventrolateral medulla, their function in the control of respiration has not yet been fully ascertained [15, 42].

In adults, infusion doses of dexmedetomidine up to $10 \mathrm{mcg} / \mathrm{kg} / \mathrm{hr}$ and plasma levels of up to $14.7 \mathrm{ng} / \mathrm{ml}$ have been reported in which apnea and airway obstruction has not ensued [15, 19-21, 43-45]. Despite the appeal of dexmedetomidine as a sedative that does not induce respiratory depression, it is stressed that central apnea and airway obstruction can occur. It is also important to clarify that the risk of apnea, as demonstrated by Belleville and Ramsay, appears to be related to both the dose and rate of dexmedetomidine infusion. Ebert noted that more pronounced respiratory effects have been reported when dexmedetomidine is rapidly infused to high concentrations [21]. The case we report demonstrates intact respiratory function on a "high-dose" dexmedetomidine infusion of $2 \mathrm{mcg} / \mathrm{kg} / \mathrm{hr}$. In comparison, Ramsay reported airway obstruction due to dexmedetomidine at infusions of $10 \mathrm{mcg} / \mathrm{kg} / \mathrm{hr}$ and Belleville reported obstructive apnea following an IV bolus of $2 \mathrm{mcg} / \mathrm{kg}$ over 2 minutes [15, 19]. These doses are five to thirty-fold greater than doses administered in this case report, though it is certainly possible that apnea can ensue at a dose of $2 \mathrm{mcg} / \mathrm{kg} / \mathrm{hr}$, or within the range of the approved FDA doses. In Ramsay's article the single report of airway obstruction was associated with desaturation, and this was resolved with a basic chin-lift. Ebert concluded that because the $\alpha_{2}$ adrenoceptor does not have an active role in the respiratory center, respiratory depression is more likely to be due to profound sedation [21, 46]. These observations are echoed by Bellivile noting that their subjects did not experience any central apneic episodes with dexmedetomidine doses up to $2 \mathrm{ug} / \mathrm{kg}$ over two minutes, however, apnea was noted secondary to airwary obstruction [15]. With clonidine, used in a single FDA approved oral dose of $0.3 \mathrm{mg}$, or with dexmedetomidine used within its FDA approved dosing, this same obstructive pattern of breathing has also been noted [38, 47, 48]. Lastly, it is important to note that the majority of these studies were conducted in young healthy adults, suggesting that though many of the 
Table 1. The Respiratory Response to Clonidine and Dexmedetomidine in Humans

\begin{tabular}{|c|c|c|c|c|}
\hline & \multicolumn{2}{|c|}{ Clonidine* } & \multicolumn{2}{|r|}{ Dexmedetomidine* } \\
\hline $\begin{array}{l}\text { Respiratory } \\
\text { Rate }\end{array}$ & $\begin{array}{l}\text { Unchanged-Minor } \\
\text { Decrease** }[38,56 \\
71-74]\end{array}$ & $\begin{array}{l}\text { Decreased }{ }^{* *}[75,76]^{\mathrm{a}} \\
\text { Increased Rate[77] }\end{array}$ & Unchanged $[21,41,78,79]$ & $\begin{array}{l}\text { Increased** (Statistically significant at target } \\
1.25 \mathrm{ng} / \mathrm{ml})[21,78] \\
\text { Decrease**[15] }(2 \mathrm{ug} / \mathrm{kg} \text { bolus over } 2 \mathrm{mins})\end{array}$ \\
\hline $\begin{array}{l}\text { Ventilation } \\
\text { (liters/minute) }\end{array}$ & $\begin{array}{l}\text { Minor Decrease** } \\
{[38,56,61,71,80]}\end{array}$ & Not specified & Unchanged [78] & $\begin{array}{l}\text { Decreased } * *[15](1, \text { and } 2 \mathrm{ug} / \mathrm{kg} \text { bolus over } 2 \mathrm{mins}) \\
\text { Unchanged [78] (Continuous infusion infusion target } \\
1.2-2.4 \mathrm{ng} / \mathrm{ml})\end{array}$ \\
\hline $\mathrm{Sp0}_{2} * * *$ & $\begin{array}{l}\text { Unchanged }[38,56 \text {, } \\
74,80,81]\end{array}$ & $\begin{array}{l}\text { Unchanged [46] (dose } \\
\text { range 400-900ug given } \\
\text { epidurally) }\end{array}$ & $\begin{array}{l}\text { Unchanged }[78,79] \\
\text { Decreased (Statistically Signifi- } \\
\text { cant at target } 0.5 \mathrm{ng} / \mathrm{ml})[21]\end{array}$ & $\begin{array}{l}\text { Decreased**[15] (1, and } 2 \mathrm{ug} / \mathrm{kg} \text { bolus over } 2 \text { mins) } \\
\text { Decreased** (Statistically Significant at target } \\
0.5 \mathrm{ng} / \mathrm{ml})[21] \\
\text { Unchanged }[78] \text { (Continuous infusion target } \\
1.2-2.4 \mathrm{ng} / \mathrm{ml})\end{array}$ \\
\hline $\mathrm{PaO}_{2}$ & $\begin{array}{l}\text { Unchanged } \\
{[46,81,82]}\end{array}$ & $\begin{array}{l}\text { Unchanged [46] (dose } \\
\text { range 400-900ug given } \\
\text { epidurally) }\end{array}$ & Unchanged $[21,41,78]$ & $\begin{array}{l}\text { Changes not statistically significant with continuous } \\
\text { infusions or bolus doses }[15,21,78]\end{array}$ \\
\hline $\mathrm{PaCO}_{2}$ & $\begin{array}{l}\text { Unchanged } \\
{[46,56,71,74]}\end{array}$ & $\begin{array}{l}\text { Unchanged [46] (dose } \\
\text { range 400-900ug given } \\
\text { epidurally) }\end{array}$ & $\begin{array}{l}\text { Unchanged [41] } \\
\text { Increased** (Statistically } \\
\text { Significant at target } 0.8 \mathrm{ng} / \mathrm{ml})[21] \\
\text { Increased trend but } \\
\text { changes not statistically } \\
\text { significant [78] }\end{array}$ & $\begin{array}{l}\text { Increased** (Statistically Significant at target } \\
0.8 \mathrm{ng} / \mathrm{ml})[21] \\
\text { Increased** }[15](1, \text { and } 2 \mathrm{ug} / \mathrm{kg} \text { bolus over } 2 \text { mins }) \\
\text { Increased trend but changes not statistically } \\
\text { significant }[78]\end{array}$ \\
\hline $\mathrm{PaO}_{2}: \mathrm{FiO}_{2}$ & Unchanged [82] & Not specified & Increased [41] & Unchanged [21] \\
\hline $\begin{array}{l}\text { Oxygen } \\
\text { Consumption }\end{array}$ & Decreased $[73,83]$ & Not specified & Unchanged [15] & $\begin{array}{l}\text { Increased at } 10 \mathrm{mins} \text {, Decreased by } 60 \mathrm{mins}[15] \text { ( } 1 \text { and } \\
2 \mathrm{ug} / \mathrm{kg} \text { bolus over } 2 \mathrm{mins})\end{array}$ \\
\hline $\begin{array}{l}\text { Carbon Dioxide } \\
\text { Production }\end{array}$ & Decreased [73] & Not specified & Unchanged [15] & $\begin{array}{l}\text { Decreased [15] }(0.25,0.5,1 \text {, and } 2 \mathrm{ug} / \mathrm{kg} \\
\text { bolus over } 2 \text { mins })\end{array}$ \\
\hline $\begin{array}{l}\text { Pulmonary } \\
\text { Vascular } \\
\text { Resistance }\end{array}$ & Decreased [84] & Not specified & Unchanged [21] & Increased (Statistically significant at $1.9 \mathrm{ng} / \mathrm{ml}$ ) [21] \\
\hline $\begin{array}{l}\text { Hypercapnic } \\
\text { Ventilatory } \\
\text { Response }^{\mathrm{f}}\end{array}$ & $\begin{array}{l}\text { Conflicting reports } \\
{[56,71-72,80,85]}\end{array}$ & Decreased [71] & Unchanged [78] & $\begin{array}{l}\text { Decreased }[15]^{\mathrm{b}}(0.25,0.5,1, \text { and } 2 \mathrm{ug} / \mathrm{kg} \\
\text { bolus over } 2 \mathrm{mins}) \\
\text { Unchanged }[78]^{\mathrm{b}}\end{array}$ \\
\hline $\begin{array}{l}\text { Risk of } \\
\text { Apnea/ } \\
\text { Hypopnea }^{c}\end{array}$ & $\begin{array}{l}\text { Yes }[38-39,46,56, \\
76,80,85,86] \\
\text { May potentiate } \\
\text { opioid induced } \\
\text { apnea [85] }\end{array}$ & Yes [75-77, 87-89] & $\begin{array}{l}\text { Yes }[47,48,97] \\
\text { No }[15,21,41,74,90] \\
\text { May potentiate opioid } \\
\text { induced apnea }[47,91]^{\mathrm{e}}\end{array}$ & $\begin{array}{l}\text { Yes }[15,19] \\
\text { May potentiate opioid induced apnea }[91]\end{array}$ \\
\hline
\end{tabular}


Table 1. contd....

\begin{tabular}{|c|c|c|c|c|}
\hline & \multicolumn{2}{|c|}{ Clonidine* } & \multicolumn{2}{|c|}{ Dexmedetomidine* } \\
\hline $\begin{array}{l}\text { Apnea/Hypopnea } \\
\text { Index }\end{array}$ & Decreased [92] & Not specified & Decreased [78] & Decreased [78] \\
\hline $\begin{array}{l}\text { Risk of Upper } \\
\text { Airway } \\
\text { Obstruction }\end{array}$ & $\begin{array}{l}\text { Yes [38, 46, 56, 80, } \\
85,86] \\
\text { Improvement } \\
\text { during sleep [92] }\end{array}$ & Yes $[75,77,87-89]^{d}$ & $\begin{array}{l}\text { Yes }[47,48,97] \\
\text { No }[15,21,41,74,90]\end{array}$ & Yes $[15,19]$ \\
\hline
\end{tabular}

Most of the data collected is from healthy human volunteers and may not be applicable in those with significant systemic disease or major co-morbidities. Percent saturation of hemoglobin as judged by pulse oximetry $\left(\mathrm{SpO}_{2}\right)$, partial pressure of oxygen within the arterial tree $\left(\mathrm{PaO}_{2}\right)$, partial pressure of carbon dioxide within the arterial tree $(\mathrm{PaCO})$, percentage of oxygen in inspired air $\left(\mathrm{FiO}_{2}\right)$.

*Clonidine is FDA approved in dosages of up to $2.4 \mathrm{mg} /$ day. The route of administration, intravenous, by mouth, or epidurally is not differentiated in regard to total dose in the table. Dexmedetomidine's maximum FDA maintenance dosing is $0.7 \mathrm{ug} / \mathrm{kg} / \mathrm{hr}$, which correlates with a plasma concentration of $1.2 \mathrm{ng} / \mathrm{ml}$ [78]

**Within clinically normal physiologic ranges.

***No statistically significant change in $\mathrm{SpO}_{2}$ without an apneic episode.

${ }^{a}$ Both reports of Decreased [75] (0.25mg in 3 year old and $0.75 \mathrm{mg}$ oral doses in 3 and 5 year olds), and Increased Rate [77] (10mg oral dose in two 34 month old children).

${ }^{\mathrm{b}}$ The discrepancy in HCVR may be due to the technique used, pseudorebreathing technique versus carbon dioxide challenge $[15,78]$.

${ }^{c}$ Distinction between central apnea and obstructive apnea not differentiated in the table, however, it appears that $\alpha_{2}$ agonists cause the majority of their apnenic episodes via obstruction, though central apnea is also possible $[15,78]$. There is also evidence that dexmedetomidine and clonidine may reduce the apnea/hypopnea index as compared to the natural sleep state $[78,92]$.

${ }^{d}$ Need for intubation with $10 \mathrm{mg}$ oral dose in two 34 month old children, single doses of $25-100 \mathrm{mg}$ of clonidine given orally have been reported without the production of apnea or upper airway obstruction $[77,93,94]$.

${ }^{\mathrm{e}} \alpha_{2}$ agonists are not likely to potentiate the respiratory depressant properties of coadministered opioid analgesics, however, there are conflicting reports within the current literature $[72,80,85,91]$.

${ }^{\mathrm{f}}$ Preterm infants, neonates, or patients in whom the blood brain barrier is disrupted may be more sensitive and have a greater reduction in the ventilatory response to carbon dioxide $[43-45,95]$.

${ }^{\mathrm{g}}$ Airway Resistance/ Bronchiolar Tone: animal studies suggest alpha 2 agonists decrease histamine-induced bronchconstriction [96].

negative effects of the $\alpha_{2}$ agonists on respiration are mild in nature, these effects could be detrimental to more frail patients with pre-existing respiratory disease or other major systemic comorbidities [15]. This documented risk of apnea and airway obstruction, especially at higher than FDA approved doses, should guide each clinician's judgment on a case-by-case basis when considering to use dexmedetomidine for procedures in which other sedatives would carry an otherwise prohibitive risk of apnea.

Dexmedetomidine has an affinity for the $\alpha_{2}: \alpha_{1}$ of $1620: 1$, and a half-life of $2.3 \mathrm{hr}$ [49]. Within the three receptor subtypes of the $\alpha_{2}, \alpha_{2 \mathrm{a}}, \alpha_{2 \mathrm{~b}}, \alpha_{2 \mathrm{c}}$, dexmedetomidine's binding affinity differs only moderately, with a 10 -fold preference for $\alpha_{2 \mathrm{a}}[50,51]$. Unlike other current sedative agents, dexmedetomidine produces a state closely resembling physiological stage 2 sleep in humans. Stage 2 sleep, which occupies 45 $55 \%$ of total sleep in adults, is characterized by sleep spindles and K-complexes, with muscular activity decreasing, and lose of awareness of the external environment. This evidence has suggested that dexmedetomidine produces its sedative effect via activation of normal non-rapid eye movement (non-Rem) sleep-promoting pathways [52]. Indeed, since non-REM sleep causes a decrease in the slope and a shift to the right of the hypercapnic ventilatory response curve (HCVR), the affects attributed to clonidine and dexmedetomidine on HCVR may be ascribed to the sleep state induced by these agents [15, 53-55]. However, since it has been shown in some studies with clonidine that a decrease in the slope of the ventilatory response to carbon dioxide $\left(\mathrm{Ve} / \mathrm{PetCO}_{2}\right)$ occurs, a direct effect of $\alpha_{2}$ agonists on respiratory centers is possibly at least partly responsible for their respiratory depressant properties
[56]. In addition to promoting non-REM sleep, clonidine suppresses rapid eye movement (REM) sleep in a dose dependent manner [56, 57].

Dexmedetomidine also has analgesic properties, with the $\alpha_{2 \mathrm{a}}$ subtype most likely being responsible for this effect both in the periphery and in central sites [58-60]. The mechanism of action appears to be activation of potassium channels, via G-protein inhibitory $\left(\mathrm{G}_{\mathrm{i}}\right)$ channel coupling with subsequent hyperpolarization of neuronal membranes, and inhibition of N-type voltage-sensitive calcium channels, via G-protein null effect $\left(G_{o}\right)$ channel coupling with decreased calcium influx and neurotransmitter release [61-64]. Furthermore, Aley and Levine have suggested that $\alpha_{2}$ antinociception is closely related to that of opioid and adenosine receptors as these receptors exhibit cross tolerance and dependence, suggesting that their underlying mechanisms are related [65]. Neuraxially, $\alpha_{2}$ receptors are located in the dorsal horn of the spinal cord in both pre- and post-synaptic neurons where their activation causes antinociception. Supraspinally, activation of $\alpha_{2}$ receptors in the locus coeruleus produces analgesia as well $[58,66-68]$. Pharmacokinetic and pharmacodynamic studies support the spinal site of action as the primary location for antinociception of $\alpha_{2}$ agonists [58].

In humans, it has been noted by Ebert, in a study of ten healthy young volunteers, that increasing plasma concentrations of dexmedetomidine, targeted ranges of $0.5,0.8,1.25$, $2,3.2,5,8 \mathrm{ng} / \mathrm{ml}$, resulted in progressive increases in sedation and analgesia, decreases in heart rate, cardiac output, and memory with a biphasic (low, then high) dose response relation for mean arterial pressure, pulmonary arterial pressure, and vascular resistances [21]. This biphasic response is 
due to the different $\alpha_{2}$ receptor subtypes, where $\alpha_{2 \mathrm{a}}$, and/ or possibly $\alpha_{2 c}$, located on the presynaptic nerve ending, decrease sympathetic outflow and blood pressure, whereas the $\alpha_{2 b}$-subtype, located on the post synaptic nerve terminal, increases blood pressure [69]. This apparent effect may be due to the 10-fold higher affinity of dexmedetomidine for the $\alpha_{2 \mathrm{a}}$, which produces hypotension, whereas following higher plasma levels, $\alpha_{2 b}$ may be activated causing the hypertensive response. Another possibility is that the sympatholytic effects of dexmedetomidine offset any direct effect on the peripheral vasculature at lower doses, but not higher doses. Of note, $10 / 10$ patients in this study were able to tolerate a targeted infusion level of $1.25 \mathrm{ng} / \mathrm{ml}$, with a progressive decline in tolerance in which only $2 / 10$ tolerated the $8.0 \mathrm{ng} / \mathrm{ml}$ targeted infusion.

Sedation increases progressively with rising dexmedetomidine concentrations. Ebert found that beginning at a targeted plasma level of $1.25 \mathrm{ng} / \mathrm{ml}$, some patients will begin to become unarousable. In terms of recall, at a plasma targeted level of $0.8 \mathrm{ng} / \mathrm{ml}$, only $2 / 10$ patients they studied had recall, and at a targeted plasma level of $1.25 \mathrm{ng} / \mathrm{ml}$, none of the study subjects had recall.

In the presented case, our primary physiologic anesthetic goal was achieved in which our patient maintained spontaneous respirations. Given the risk of pending airway collapse, and the infeasibility of securing an endotracheal or primary surgical airway, the attributes of the use of higher doses of dexmedetomidine proved very useful. If our initial anesthetic plan failed, we intended to progressively increase the dose of dexmedetomidine and employ local anesthetics in a "spray as you go" fashion through the bronchoscope. We also had ketamine available to use in small quantities if we felt that it was needed. The combined use of FDA approved doses of dexmedetomidine and low-dose ketamine has been described for awake fiberoptic intubations [70]. Ultimately, cardiopulmonary bypass was available in the event of total airway collapse.

\section{CONCLUSIONS}

Higher doses of dexmedetomidine, above that which is currently FDA approved, can result in progressive increases in sedation and analgesia, with resultant unresponsiveness to some surgical stimuli, and decreases in memory, with the potential for minimal to no clinical effects on spontaneous respirations, and stable hemodynamics, though apnea is possible. This case report adds to a growing body of literature, which suggests that in properly selected patients, higher than FDA recommended doses of dexmedetomidine may be safe for adult use, and in cases where spontaneous respiration must be maintained, may offer the safest anesthetic option when other sedatives carry a prohibitive risk of apnea. Ultimately, large randomized controlled studies are needed to more definitively answer these questions.

\section{DECLARATION OF FUNDING}

The authors have not received funding for this manuscript.

\section{DECLARATION OF INTEREST}

The authors declare no conflicts of interest.

\section{REFERENCES}

[1] Blank RS, de Souza DG. Anesthetic management of patients with an anterior mediastinal mass: continuing professional development. Can J Anaesth 2011; 58: 853-67.

[2] Anghelescu DL, Burgoyne LL, Liu T, et al. Clinical and diagnostic imaging findings predict anesthetic complications in children presenting with malignant mediastinal masses. Paediatr Anaesth 2007; 17: 1090-8.

[3] Bechard P, Letourneau L, Lacasse Y, Cote D, Bussieres JS Perioperative cardiorespiratory complications in adults with mediastinal mass: incidence and risk factors. Anesthesiology 2004; 100: 826-34; discussion 5A.

[4] Hack HA, Wright NB, Wynn RF. The anaesthetic management of children with anterior mediastinal masses. Anaesthesia 2008; 63: 837-46.

[5] King DR, Patrick LE, Ginn-Pease ME, McCoy KS, Klopfenstein K. Pulmonary function is compromised in children with mediastinal lymphoma. J Pediatr Surg 1997; 32: 294-9; discussion 9-300.

[6] Shamberger RC, Holzman RS, Griscom NT, Tarbell NJ, Weinstein HJ. CT quantitation of tracheal cross-sectional area as a guide to the surgical and anesthetic management of children with anterior mediastinal masses. J Pediatr Surg 1991; 26: 138-42.

[7] Shamberger RC. Preanesthetic evaluation of children with anterior mediastinal masses. Semin Pediatr Surg 1999; 8: 61-8.

[8] Shamberger RC, Holzman RS, Griscom NT, Tarbell NJ, Weinstein HJ, Wohl ME. Prospective evaluation by computed tomography and pulmonary function tests of children with mediastinal masses. Surgery $1995 ; 118: 468-71$.

[9] Stricker PA, Gurnaney HG, Litman RS. Anesthetic management of children with an anterior mediastinal mass. J Clin Anesth 2010; 22: 159-63.

[10] Huang YL, Yang MC, Huang CH, et al., Rescue of cardiopulmonary collapse in anterior mediastinal tumor: case presentation and review of literature. Pediatr Emerg Care 2010; 26: 296-8.

[11] Takeda S, Miyoshi S, Omori K, Okumura M, Matsuda H. Surgical rescue for life-threatening hypoxemia caused by a mediastinal tumor. Ann Thorac Surg 1999; 68: 2324-6.

[12] Wahba RW. Perioperative functional residual capacity. Can J Anaesth 1991; 38: 384-400.

[13] Navarrete-Navarro P, Vazquez G, Fernandez E, Torres JM, Reina A, Hinojosa R. Mediastinal, left, and right atrial pressure variations with different modes of mechanical and spontaneous ventilation. Crit Care Med 1989; 17: 563-6.

[14] Segal IS, Vickery RG, Walton JK, Doze VA, Maze M. Dexmedetomidine diminishes halothane anesthetic requirements in rats through a postsynaptic alpha 2 adrenergic receptor. Anesthesiology 1988; 69: 818-23.

[15] Belleville JP, Ward DS, Bloor BC, Maze M. Effects of intravenous dexmedetomidine in humans. I. sedation, ventilation, and metabolic rate. Anesthesiology 1992; 77: 1125-33.

[16] Kamibayashi T, Maze M. Clinical uses of alpha2 -adrenergic agonists. Anesthesiology 2000; 93: 1345-9.

[17] Mehta S, Myat HM. The cross-sectional shape and circumference of the human trachea. Ann R Coll Surg Engl 1984; 66: 356-8.

[18] Abdelmalak B, Makary L, Hoban J, Doyle DJ. Dexmedetomidine as sole sedative for awake intubation in management of the critical airway. J Clin Anesth 2007; 19: 370-3.

[19] Ramsay MA, Luterman DL. Dexmedetomidine as a total intravenous anesthetic agent. Anesthesiology 2004; 101: 787-90.

[20] Ramsay MA, Saha D, Hebeler RF. Tracheal resection in the morbidly obese patient: the role of dexmedetomidine. J Clin Anesth 2006; 18: 452-4.

[21] Ebert TJ, Hall JE, Barney JA, Uhrich TD, Colinco MD. The effects of increasing plasma concentrations of dexmedetomidine in humans. Anesthesiology 2000; 93: 382-94.

[22] Kunisawa T, Nagata O, Iwasaki H. Pharmacokinetic simulation of high-dose administration of dexmedetomidine for decubitus treatment. Masui 2006; 55: 995-8.

[23] Kunisawa T, Ota M, Suzuki A, Takahata O, Iwasaki H. Combination of high-dose dexmedetomidine sedation and fascia iliaca compartment block for hip fracture surgery. J Clin Anesth 2010; 22: 196-200. 
[24] Kunisawa T, Suzuki A, Takahata O, Iwasaki H. High dose of dexmedetomidine was useful for general anesthesia and postoperative analgesia in a patient with postpolio syndrome. Acta Anaesthesiol Scand 2008; 52: 864-5.

[25] Ohata H, Tanemura E, Dohi S. Use of high-dose dexmedetomidine infusion for anesthesia and sedation in a patient for microlaryngeal surgery maintained with spontaneous breathing. Masui 2008; 57: 428-32.

[26] Mason KP, Zurakowski D, Zgleszewski SE, et al. High dose dexmedetomidine as the sole sedative for pediatric MRI. Paediatr Anaesth 2008; 18: 403-11.

[27] Mahmoud M, Radhakrishman R, Gunter J, et al. Effect of increasing depth of dexmedetomidine anesthesia on upper airway morphology in children. Paediatr Anaesth 2010; 20: 506-15.

[28] O'Halloran KD, Herman JK, Bisgard GE. Differential effects of clonidine on upper airway abductor and adductor muscle activity in awake goats. J Appl Physiol 1999; 87: 590-7.

[29] O'Halloran KD, Herman JK, Bisgard GE. Clonidine induces upper airway closure in awake goats. Respir Physiol 2000; 123: 165-76.

[30] Andrade R, Aghajanian GK. Single cell activity in the noradrenergic A-5 region: responses to drugs and peripheral manipulations of blood pressure. Brain Res 1982; 242: 125-35.

[31] Andrade R, Aghajanian GK. Opiate- and alpha 2-adrenoceptorinduced hyperpolarizations of locus ceruleus neurons in brain slices: reversal by cyclic adenosine 3': 5'-monophosphate analogues. J Neurosci 1985; 5: 2359-64.

[32] Champagnat J, Denavit-Saubie M, Henry JL, Leviel V. Catecholaminergic depressant effects on bulbar respiratory mechanisms. Brain Res 1979; 160: 57-68.

[33] McCrimmon DR, Lalley PM. Inhibition of respiratory neural discharges by clonidine and 5-hydroxytryptophan. J Pharmacol Exp Ther 1982; 222: 771-7.

[34] Bamford OS, Dawes GS, Denny R, Ward RA. Effects of the alpha 2 -adrenergic agonist clonidine and its antagonist idazoxan on the fetal lamb. J Physiol 1986; 381: 29-37.

[35] Burton MD, Johnson DC, Kazemi H. Adrenergic and cholinergic interaction in central ventilatory control. J Appl Physiol 1990; 68: 2092-9.

[36] Lavoie JP, Pascoe JR, Kurpershoek CJ. Effects of xylazine on ventilation in horses. Am J Vet Res 1992; 53: 916-20.

[37] Zornow MH. Ventilatory, hemodynamic and sedative effects of the alpha 2 adrenergic agonist, dexmedetomidine. Neuropharmacology 1991; 30: 1065-71.

[38] Benhamou D, Veillette Y, Narchi P, Ecoffey C. Ventilatory effects of premedication with clonidine. Anesth Analg 1991; 73: 799-803.

[39] Narchi P, Benhamou D, Hamza J, Bouaziz H. Ventilatory effects of epidural clonidine during the first 3 hours after caesarean section. Acta Anaesthesiol Scand 1992; 36: 791-5.

[40] Bloor BC, Abdul-Rasool I, Temp J, Jenkins S, Valcke C, Ward DS. The effects of medetomidine, an alpha 2-adrenergic agonist, on ventilatory drive in the dog. Acta Vet Scand Suppl 1989; 85: 65-70.

[41] Venn RM, Hell J, Grounds RM. Respiratory effects of dexmedetomidine in the surgical patient requiring intensive care. Crit Care 2000; 4: 302-8.

[42] Unnerstall JR, Kopajtic TA, Kuhar MJ. Distribution of alpha 2 agonist binding sites in the rat and human central nervous system: analysis of some functional, anatomic correlates of the pharmacologic effects of clonidine and related adrenergic agents. Brain Res 1984; 319: 69-101.

[43] Fellmann C, Gerber AC, Weiss M. Apnoea in a former preterm infant after caudal bupivacaine with clonidine for inguinal herniorrhaphy. Paediatr Anaesth 2002; 12: 637-40.

[44] Galante D. Preoperative apnea in a preterm infant after caudal block with ropivacaine and clonidine. Paediatr Anaesth 2005; 15: 708-9.

[45] Rangan C, Everson G, Cantrell FL. Central alpha-2 adrenergic eye drops: case series of 3 pediatric systemic poisonings. Pediatr Emerg Care 2008; 24: 167-9.

[46] Eisenach JC, Lysak SZ, Viscomi CM. Epidural clonidine analgesia following surgery: phase I. Anesthesiology 1989; 71: 640-6.

[47] Itagaki T, Uchisaki S, Adachi Y, et al. Apnea and severe respiratory depression induced by dexmedetomidine after general anesthesia in intensive care unit. Masui 2009; 58: 1534-7.

[48] Candiotti KA, Bergese SD, Bokesch PM, Feldman MA, Wisemandle W, Bekker AY. Monitored anesthesia care with dexmedetomidine: a prospective, randomized, double-blind, multicenter trial. Anesth Analg 2010; 110: 47-56.

[49] Gertler R, Brown HC, Mitchell DH, Silvius EN. Dexmedetomidine: a novel sedative-analgesic agent. Proc (Bayl Univ Med Cent) 2001; 14: 13-21.

[50] Piletz JE, Zhu H, Chikkala DN. Comparison of ligand binding affinities at human I1-imidazoline binding sites and the high affinity state of alpha-2 adrenoceptor subtypes. J Pharmacol Exp Ther 1996; 279: 694-702.

[51] MacDonald E, Kobilka BK, Scheinin M. Gene targeting--homing in on alpha 2-adrenoceptor-subtype function. Trends Pharmacol Sci 1997; 18: 211-9.

[52] Huupponen E, Maksimow A, Lapinlampi P, et al. Electroencephalogram spindle activity during dexmedetomidine sedation and physiological sleep. Acta Anaesthesiol Scand 2008; 52: 289-94.

[53] Bellville JW, Howland WS, Seed JC, Houde RW. The effect of sleep on the respiratory response to carbon dioxide. Anesthesiology 1959; 20: 628-34.

[54] Douglas NJ, White DP, Weil JV, Pickett CK, Zwillich CW. Hypercapnic ventilatory response in sleeping adults. Am Rev Respir Dis 1982; 126: 758-62.

[55] Reed DJ, Kellogg RH. Changes in respiratory response to $\mathrm{CO} 2$ during natural sleep at sea level and at altitude. J Appl Physiol 1958; 13: 325-30.

[56] Penon C, Ecoffey C, Cohen SE. Ventilatory response to carbon dioxide after epidural clonidine injection. Anesth Analg 1991; 72: 761-4.

[57] Spiegel R, DeVos JE. Central effects of guanfacine and clonidine during wakefulness and sleep in healthy subjects. $\mathrm{Br} \mathrm{J}$ Clin Pharmacol 1980; 10 (Suppl 1): 165S-8S

[58] Chan AK, Cheung CW, Chong YK. Alpha-2 agonists in acute pain management. Expert Opin Pharmacother 2010; 11: 2849-68.

[59] Kingery WS, Guo TZ, Davies MF, Limbird L, Maze M. The alpha(2A) adrenoceptor and the sympathetic postganglionic neuron contribute to the development of neuropathic heat hyperalgesia in mice. Pain 2000; 85: 345-58.

[60] Smith H, Elliott J. Alpha(2) receptors and agonists in pain management. Curr Opin Anaesthesiol 2001; 14: 513-8.

[61] Khan ZP, Ferguson CN, Jones RM. alpha-2 and imidazoline receptor agonists. their pharmacology and therapeutic role. Anaesthesia 1999; 54: 146-65.

[62] Lipscombe D, Kongsamut S, Tsien RW. Alpha-adrenergic inhibition of sympathetic neurotransmitter release mediated by modulation of N-type calcium-channel gating. Nature 1989; 340: 639-42.

[63] Maze M, Tranquilli W. Alpha-2 adrenoceptor agonists: defining the role in clinical anesthesia. Anesthesiology 1991; 74: 581-605.

[64] Scholz J, Tonner PH. Alpha2-adrenoceptor agonists in anaesthesia: a new paradigm. Curr Opin Anaesthesiol 2000; 13: 437-42.

[65] Aley KO, Levine JD. Multiple receptors involved in peripheral alpha 2, mu, and $\mathrm{A} 1$ antinociception, tolerance, and withdrawal. J Neurosci 1997; 17: 735-44.

[66] Calvillo O, Ghignone M. Presynaptic effect of clonidine on unmyelinated afferent fibers in the spinal cord of the cat. Neurosci Lett 1986; 64: 335-9.

[67] Correa-Sales C, Rabin BC, Maze M. A hypnotic response to dexmedetomidine, an alpha 2 agonist, is mediated in the locus coeruleus in rats. Anesthesiology 1992; 76: 948-52.

[68] Ono H, Mishima A, Ono S, Fukuda H, Vasko MR. Inhibitory effects of clonidine and tizanidine on release of substance P from slices of rat spinal cord and antagonism by alpha-adrenergic receptor antagonists. Neuropharmacology 1991; 30: 585-9.

[69] Philipp M, Brede M, Hein L. Physiological significance of alpha(2)-adrenergic receptor subtype diversity: one receptor is not enough. Am J Physiol Regul Integr Comp Physiol 2002; 283: R287-95.

[70] Scher CS, Gitlin MC. Dexmedetomidine and low-dose ketamine provide adequate sedation for awake fibreoptic intubation. Can J Anaesth 2003; 50: 607-10.

[71] Ooi R, Pattison J, Feldman SA. The effects of intravenous clonidine on ventilation. Anaesthesia 1991; 46: 632-3.

[72] Jarvis DA, Duncan SR, Segal IS, Maze M. Ventilatory effects of clonidine alone and in the presence of alfentanil, in human volunteers. Anesthesiology 1992; 76: 899-905. 
[73] Liatsi D, Tsapas B, Pampori S, Tsagourias M, Pneumatikos I, Matamis D. Respiratory, metabolic and hemodynamic effects of clonidine in ventilated patients presenting with withdrawal syndrome. Intensive Care Med 2009; 35: 275-81.

[74] Hall JE, Uhrich TD, Barney JA, Arain SR, Ebert TJ. Sedative, amnestic, and analgesic properties of small-dose dexmedetomidine infusions. Anesth Analg 2000; 90: 699-705.

[75] Mathew PM, Addy DP, Wright N. Clonidine overdose in children. Clin Toxicol 1981; 18: 169-73.

[76] Stein B, Volans GN. Dixarit overdose: the problem of attractive tablets. Br Med J 1978; 2: 667-8.

[77] Maggi JC, Iskra MK, Nussbaum E. Severe clonidine overdose in children requiring critical care. Clin Pediatr (Phila) 1986; 25: 453-5.

[78] Hsu YW, Cortinez LI, Robertson KM, et al. Dexmedetomidine pharmacodynamics: part I: crossover comparison of the respiratory effects of dexmedetomidine and remifentanil in healthy volunteers. Anesthesiology 2004; 101: 1066-76.

[79] Martin E, Ramsay G, Mantz J, Sum-Ping ST. The role of the alpha2-adrenoceptor agonist dexmedetomidine in postsurgical sedation in the intensive care unit. J Intensive Care Med 2003; 18 : 29-41.

[80] Bailey PL, Sperry RJ, Johnson GK, et al. Respiratory effects of clonidine alone and combined with morphine, in humans. Anesthesiology 1991; 74: 43-8.

[81] Zochowski RJ, Lada W. Intravenous clonidine in acute myocardial infarction in men. Int J Cardiol 1984; 6: 189-205.

[82] De Kock M, Henin D, Singelyn F, Gouverneur JM. Intravenous clonidine does not promote hypoxemia or platelet aggregation in man. Acta Anaesthesiol Belg 1993; 44: 11-5.

[83] Delaunay L, Bonnet F, Duvaldestin P. Clonidine decreases postoperative oxygen consumption in patients recovering from general anaesthesia. Br J Anaesth 1991; 67: 397-401.

[84] Giles TD, Iteld BJ, Mautner RK, Rognoni PA, Dillenkoffer RL. Short-term effects of intravenous clonidine in congestive heart failure. Clin Pharmacol Ther 1981; 30: 724-8.

[85] Luebbe N, Walz R, Walz K, Kiesel C, Bornscheuer A. Clonidine prolongs fentanyl-induced ventilatory depression. Eur J Anaesthesiol 1998; 15: 292-6.
[86] Eisenach JC. Intravenous clonidine produces hypoxemia by a peripheral alpha-2 adrenergic mechanism. J Pharmacol Exp Ther 1988; 244: 247-52.

[87] Anderson RJ, Hart GR, Crumpler CP, Lerman MJ. Clonidine overdose: report of six cases and review of the literature. Ann Emerg Med 1981; 10: 107-12.

[88] Artman M, Boerth RC. Clonidine poisoning. A complex problem. Am J Dis Child 1983; 137: 171-4.

[89] Conner CS, Watanabe AS. Clonidine overdose: a review. Am J Hosp Pharm 1979; 36: 906-11.

[90] Chawla S, Robinson S, Norton A, Esterman A, Taneerananon T. Peri-operative use of dexmedetomidine in airway reconstruction surgery for obstructive sleep apnoea. J Laryngol Otol 2010; 124: $67-72$.

[91] Uzumcugil F, Canbay O, Celebi N, Karagoz AH, Ozgen S. Comparison of dexmedetomidine-propofol vs. fentanyl-propofol for laryngeal mask insertion. Eur J Anaesthesiol 2008; 25: 675-80.

[92] Issa FG. Effect of clonidine in obstructive sleep apnea. Am Rev Respir Dis 1992; 145: 435-9.

[93] Oliver Rotellar JA, Sedano Monasterio E, Sabate de la Cruz J, Gausi Gene C. Clonidine in thousand-fold overdose. Lancet 1981; 1: 1312 .

[94] Lilja M, Hakala M, Jounela AJ. Hypertension after clonidine overdose. A case report. Ann Clin Res 1984; 16: 10-2.

[95] Breschan C, Krumpholz R, Likar R, Kraschl R, Schalk HV. Can a dose of 2 microg. $\mathrm{kg}(-1)$ caudal clonidine cause respiratory depression in neonates?. Paediatr Anaesth 1999; 9: 81-3.

[96] Lou YP, Franco-Cereceda A, Lundberg JM. Variable alpha 2adrenoceptor-mediated inhibition of bronchoconstriction and peptide release upon activation of pulmonary afferents. Eur J Pharmacol 1992; 210: 173-81.

[97] Bergese SD, Candiotti KA, Bokesch PM, et al. A Phase IIIb, randomized, double-blind, placebo-controlled, multicenter study evaluating the safety and efficacy of dexmedetomidine for sedation during awake fiberoptic intubation. Am J Ther 2010; 17(6): 586-595.

Received: October 10, 2011

Revised: November 10, 2011

Accepted: November 11, 2011

(C) Voscopoulos et al:; Licensee Bentham Open.

This is an open access article licensed under the terms of the Creative Commons Attribution Non-Commercial License (http://creativecommons.org/licenses/ by-nc/3.0/) which permits unrestricted, non-commercial use, distribution and reproduction in any medium, provided the work is properly cited. 